\title{
N. F. S. Grundtvigs "Studier til en bibelsk Rimkrønike" (1828) set i lyset af hans samtidige kristeligt pædagogiske tanker
}

\section{Af Else Riisager}

Grundtvig skrev bibel- og kirkehistoriske salmer og sange 1810-70, det vil sige, at han praktisk talt hele sit produktive liv var optaget af at formidle det bibelske og kirkehistoriske stof $\mathrm{i}$ en digterisk form, der først og fremmest appellerede til børn, unge og lægmænd. "Studier til en bibelsk Rimkrønike" fra 1828 er Grundtvigs første forsøg på en systematisk udgivelse af bibelhistoriske digte for børn til skolebrug. I hans samlede udgave af genren, SangVoerk til Den Danske Kirke-Skole (1870) (GSV II), er digtene fra studierne optaget som nummer 1, 2, 6, 7 og 8 .

Bidraget behandler Grundtvigs overvejelser over den kristelige pædagogik i forhold til målgruppen omkring udgivelsestidspunktet, specielt med henblik på den overordnede hensigt med digtene samt deres genre og brug. Hans praksis demonstreres gennem en alsidig eksempelanalyse af "Kain pløied rask i Vaar" ( $G S V$ II, nr. 6) og en mere tematisk præsentation af de øvrige digte. Afsluttende sammenholdes teksterne $\mathrm{i}$ "Studier til en bibelsk Rimkrønike" med hans samtidige kristeligt pædagogiske tanker.

\section{Indledning}

Årene umiddelbart før udgivelsen af "Studier til en bibelsk Rimkrønike", 1828, ${ }^{1}$ er kendetegnet ved en ændring af, hvad Grundtvig opfatter som kriteriet for sand kristendom. I den kristelige pædagogik giver den sig udslag i en forandret opfattelse af konfirmationen og konfirmationsforberedelsen fra foråret 1824, og den indtræder mest markant med hans "mageløse Opdagelse" i sommeren 1825. Den teologiske nybesindelse udvikles som bekendt i teologiske afhandlinger i perioden og bliver benævnt hans kirkelige anskuelse. Nybesindelsen får især betydning for den kristelige pædagogik via et ændret bibelsyn, forestillingen om "det levende Ord", opfattelsen af forholdet mellem kirke og skole samt en begyndende sondring mellem det menneskelige og kristelige.

Grundtvigs litterære produktion skifter også karakter på denne tid efter kraftanstrengelserne med de store oversættelsesarbejder og Nyaars-Morgen fra 1824. Han ønsker ikke længere at gøre sig

I Theologisk Maanedsskrift XIII, 145-181, 1828, imprimatur 14. juli 1828; forkortet $S B R K$. Digtene i $S B R K$ benævnes efter deres numre i GSV II. 
gældende på samtidens litterære parnas, men værker som de bibelhistoriske digte kan dog betragtes som hans særegne version af tidens toneangivende litterære stil, poetisk realisme. I hans verdslige digte, salmer og i de bibelhistoriske salmer og sange kan man ligeledes spore en afsmittende stilistisk effekt fra de tidligere års arbejde med den norrøne poesi, ligesom han henter inspiration fra sine studier i Den danske Rimkrønike. Den fornyede interesse for at beskæftige sig med de bibel- og kirkehistoriske salmer og sange er opstået i forbindelse med undervisningen af hans sønner, og ved at han som præst fra 182126 igen har konfirmandundervisning.

\section{Bibel- og kirkehistoriske fortællinger med forkyndende hensigt}

På samme tid som Grundtvig offentliggør "Studier til en bibelsk Rimkrønike", udsender han to andre pædagogiske udgivelser til samme målgruppe, En liden Bibel-Krønike for Børn og Menig-Mand, ${ }^{2}$ også fra 1828, og Krønike-Riim til Børne-Lordom fra 1829. ${ }^{3}$ De teologiske nyvindinger sætter naturligt sit præg på fortalerne til disse værker. Med forbehold kan man betragte disse fortaler under ét, da udgivelserne har mange lighedspunkter: Fortalerne er skrevet i løbet af maj-december 1828, "Krønike" indgår i alle titler, målgrupperne for værkerne er børn, unge og lægmænd, værkerne er eller er dele af lærebøger, Bibel-Krøniken og studierne har samme stof, mens studierne og Krønike-Riimene er på vers.

Selv om Bibelen ikke længere er kriteriet for sand kristendom og grundlaget for frelse, er den "alle Christne lige uundværlig". ${ }^{4}$ Stoffet $\mathrm{i}$ første udgave af bibelhistorien fra $1814^{5}$ gav "de yderste Omrids af Guds Folks Historie i begge Testamenter" og noget tilsvarende indeholder den nye udgave. "Ligeledes er det mig soleklart, at alle christne Børn, efter Evne og Leilighed, bør giøres bekiendte med den christne Troes og Menigheds Skæbne i Verden". Grundtvig betoner, at børnene $i$ et passende omfang skal have "den nødvendige eller dog høistnyttige Bibelkundskab". ' Viden om bibel- og kirkehistorien er således en uomgængelig del af den kristne opdragelse. I sprogbrugen giver Grundtvig et fingerpeg om, hvad der er "den nødvendige Bibelkundskab" ved at bruge ordene "Guds Folk", dvs. de udvalgte og

\footnotetext{
2. omarb. udg., imprimatur 18. maj 1828; forkortet $L B K 1828$.

Fortale og indledning dateret 27. december 1828; forkortet $K R 1829$.

Om Christendommens Sandhed (US IV, 557).

En liden Bibelkrønike for Børn og Menigmand; forkortet LBK 1814.

$L B K 1828$, V.

LBK 1828, VII.
} 
specielt de gudfrygtige, og "den christne Tro og Menighed" i modsætning til overordnede betegnelser som jødedom eller kristendom. ${ }^{8}$ Det er netop de menneskelige vidnesbyrd om det rette gudsforhold og den levende tro i Bibelen og kirkehistorien, der viser den sande kristendom. $^{9}$

Mens Bibelen er "uundværlig", skal den tolkes og formidles til børnene med udgangspunkt $\mathrm{i}$ "det Uundvorligste". 10 "Langt er jeg fra den Mening, at nogen, Lære-Bog stort, end sige da en Bibel-Krønike kan nytte Børn, med mindre Forældrene, eller Andre i deres Sted, lade Troens levende Ord følge med, som Aanden og Nøgelen". ${ }^{11}$ Den kristne bekendelse, konkretiseret i den apostolske trosbekendelse, skal således være nøglen til tolkningen eller forståelsesbaggrunden for teksterne i bibel- og kirkehistorien. Samtidig skal formidlingen af ånden eller essensen af bekendelsen gives mundtligt af forældrene eller en lærer i undervisningssituationen. Bogen er da også tilegnet "Christelige Forceldre og Børn". Forældrene eller en lærer i deres sted skal altså personligt stå inde for dens budskab. Tilegnelsen angiver desuden, at børnene er kristne, før de får undervisning i bibelhistorien, og det er de jo netop ved i barnedåben at være døbte på den apostolske trosbekendelse. Bugge påpeger, at Grundtvig $i$ et notat lægger vægt på, "at først når børnene har lært deres dåbspagt at kende, først da er det tid at give dem indblik i Guds nåde og hans førelse af menneskeslægten". ${ }^{12}$

Den mundtlige tolkning af teksterne ud fra trosbekendelsen er altså forudsætningen for, at Bibel-Krøniken kan være til nytte. Bogen er givet "Forældre og Børn, til christelig Brug". Forfatteren overrækker dem bogen "i Jesu Navn" med en strofe, der fortæller, at al virksomhed, der begynder i hans navn, mere og mere går fremad, gavner og glæder, indtil målet nås i Guds Rige. ${ }^{13}$ Nytten af og hensigten med bibel- og kirkehistorien er således, at den skal hjælpe sine brugere til at opnå evigt liv. I den middelalderlige, firefoldige teksttolkning svarer det til, at de i deres trosforhold kan nå det, der er beskrevet som det 4 . niveau (det eskatologiske). Den overordnede hensigt er kristologisk

8 Jf. Høirups beskrivelse af LBK 1828, hvis indhold "dristigt gennemfører opfattelsen af åbenbaringshistorien som menighedshistorie", og at "bogen tydeligt [er] anlagt som en indføring i menighedens fællesskab" (Høirup 1962, 69).

9 Se fx Thodberg et al. 1983, $241 \mathrm{f}$.

10 LBK $1828, \mathrm{~V}$.

$11 \quad L B K 1828$, VI.

12 Bugge 1965, 240 med note 137. Notatet er et forarbejde til Christelige Prcedikener eller Søndags-Bog, I-III, 1827-30(31).

13 LBK 1828, VIII. 
forkyndelse med den apostolske trosbekendelse som indholdsmæssig klangbund for forståelsen.

Den kundskabsmeddelende hensigt med bibel- og kirkehistorien er dermed underordnet den forkyndende. Dette er specielt tilfældet for en "Bibel-Krønike", men som det fremgår af citatet ovenfor, gælder det også for andre lærebøger, at den mundtlige formidling og den holdningsmæssige forankring i trosbekendelsen hos en voksen skal ledsage læsningen i lærebogen. Det er forudsætningen for, at lærebogen kan "nytte".

Også digtene og eksplicit fortalen til "Studier til en bibelsk Rimkrønike" er beregnet til "christelige Læsere", ${ }^{14}$ og da fortalen er dateret to måneder efter Bibel-Krønikens, er de ovenfor beskrevne forhold omkring den forkyndende hensigt også gyldige for denne udgivelse og ligger som en uudtalt forudsætning i fortalens udsagn.

Grundtvig fremhæver, at "det Praktiske, det er og bliver HovedSagen i Livet, i det Aandelige saavelsom i det Legemlige" i modsætning til teoretiske udredninger i den samtidige strid om Kirke-Sagen og Skole-Sagen" eller "mine Tanker om Poesiens Forhold til Christendommen, og om Maaden, vi skulde stræbe at undgaae de Klipper og Skjær, man hidtil stødte paa". ${ }^{16}$ I hvert fald på dette tidspunkt mener han, at praksis, in casu bibelhistoriske digte for børn, er vigtigere for ham til fremme af hans forkyndende hensigter end teoretiske afhandlinger. Han belægger udsagnet ved at henvise til 1 Kor 4,20 om, "at Guds Rige bestaar ikke i Snak men i Kraft", og fortsætter, idet han alluderer til Sl 33,9, at Guds Ord er en "Kraft, som, hvor den annammes, virkelig frembringer, hvad den levende udtrykker!". ${ }^{17}$ Det vil sige, at når Guds ord tages imod, skaber det sin egen virkelighed. I det samtidige digt "Jeg er saa underfuld en Magt" fra Krønike-Riim lader han Gud fastslå det samme på denne måde: "Min Gaade er et Guddoms-Ord, / Som skaber hvad jeg nævner" (str. 10). ${ }^{18}$ Grundtvig udtrykker fortrøstning til, at når "christelig Aand og Praxis" er til stede, vil alt blive så kristeligt, som det er muligt. ${ }^{19}$ Forkyndende mission lykkes, når det - som her - er tilfældet med digteren og tilsva-

\section{$14 S B R K, 146$.}

15 Foruden i Kirkens Gienmoele, 1825 (VU II, 317-349) forfægter Grundtvig sine synspunkter i "Om den sande Christendom" og "Om Christendommens Sandhed", 12 afhandlinger i Theologisk Maanedsskrift 1826-27, samt i "Skal den Lutherske Reformation virkelig fortsættes?", 1830-31, i J. C. Lindbergs Maanedsskrift for Christendom og Historie.

16 SBRK, $146 \mathrm{f}$.

17 SBRK, $146 \mathrm{f}$. Andre lignende skriftsteder: Sl 148,5; 33,6.

$18 K R 1829$ No. LII; jf. GSV II, nr. 134.

19 SBRK, 147. 
rende $\mathrm{i}$ undervisningssituationen hos børn og forældre, for så bliver Guds ord til levende realitet for dem.

Med allusion til "Fadervor" og de tre trosartikler sammenfatter Grundtvig $\mathrm{i}$ et udkast til forordet til bibelhistorien hensigten med en "bibelsk og kirkelig Børne-Bog, (...) som jo er at give Smaa-Christne en levende og yndig Forestilling om vor Fader, som er i Himlene, om Hans eenbaarne Søn, som blev vor Broder, og Hans gode Aand, som vil være vor evige Trøster og Talsmand, saa de kan lære at skiønne paa den Lykke, dem timedes, at fødes og opammes i Kirkens Skjød, og saa den christelige Sandhed kan uforglemmelig indprænte sig i deres bløde Hjerte og stærke Ihukommelse." 20

\section{Levende fortællinger på vers}

Den bibelske og kirkelige Børne-Bog, der opfylder Grundtvigs hensigter, tror han bedst at kunne skabe i en genre, der har karakter af "en Bibelsk Rim-Krønike". ${ }^{21}$

Grundtvig blev tidligt optaget af Den danske Rimkrønike, ${ }^{22}$ en danmarkshistorie på episk-dramatiske vers, hvor hver konge i monologform fortæller om sit liv og levned. Det historiske stof er krydret med ordsprog og talemåder fra for eksempel folkeviser og Bibelen og har ud over det historisk oplysende underholdende og moraliserende intentioner. I prologen står der, at skildringen af gode og onde konger skal tjene som eksempler til afstandtagen eller efterfølgelse: "Ere the [de] ondæ man maa them fly / Ere the godæ man maa them thy [slutte sig til]". ${ }^{23}$

Grundtvigs fascination stammer fra ca. 1815 og holdt sig livet ud. Ud over at udgive dele af Rimkrøniken i blandt andet Danne-Virke skrev han filologiske afhandlinger om dens oprindelse og digtede en fortsættelse med kongeskildringer ført op til samtiden. ${ }^{24}$ Grundtvig bevidner om "denne min Liv-Bog", at han havde læst den tiere end Bibelen, ${ }^{25}$ og at han af Rimkrøniken og Peder Laales ordsprog "lærde mere Dansk, end der i alle vor Tids Bøger er at finde". ${ }^{26}$ Den sproglige påvirkning kan aflæses $\mathrm{i}$ hans fordanskninger af Snorre, Saxo og Beowulf, som han jo som bekendt skrev på "borgestuedansk" til brug

20 Grundtvig-arkivet, fasc. 146.8.b.; her citeret efter Bugge 1978, 43.

21 Ibid.

22 Forfattet inden 1477, trykt 1495 hos Gotfred af Ghemen.

23 Toldberg (1961), 4.

24 PS V, 390-405; VI, 74-121.

25 Nordisk Kirke-Tidende, 1834, sp. 549; efter Toldberg 1954, 60.

26 Fra artiklen "Om Ordsprog” (US III, 504); efter Toldberg 1954, 53. 
for menigmand. ${ }^{27}$ Inspirationen sætter sig også spor i værktitler som "Et Blad af Jyllands Rimkrønike". ${ }^{28}$

Omkring 1828 er det Grundtvigs foretrukne ide på det kristeligt pædagogiske område at udskifte stoffet fra den verdslige danske historie med Bibelen og skabe en bibelhistorie på vers med genremæssige træk fra rimkrøniken. I fortalen til bibelhistorien skriver han:

Endelig maa jeg erindre, at til mine Børns Lære-Bøger ønskede jeg helst idel Rim-Krøniker, som give den letteste og livligste BogLæsning, men deels har vel Mange Fordom mod en bibelsk RimKrønike, og deels vilde den være ligesaa vanskelig at skrive, som let at læse. Føleligt vil Savnet heller ikke være, naar vi bruge vore christne Forældres prøvede Huus-Raad: at lade Børnene tidlig begynde og seent holde op at lære historiske Psalmer, som er et af de ypperste Midler til at indprænte dem Christendommen blidelig, levende, og uforglemmelig! $!^{29}$

"Studier til en bibelsk Rimkrønike" er, hvad Grundtvig selv betegner som "et af mine vragede Forsøg". ${ }^{30} \mathrm{Da}$ han med Krønike-Riim til Børne-Laerdom i 1829 gengiver universalhistorien i samme genre, lykkes dette mere almene pædagogiske projekt.

Det er først i disse år, at Grundtvig bevidst begynder at fremhæve verset som et virksomt pædagogisk hjælpemiddel. Hvor han tidligere som i artiklen i Sandsigeren har peget på historiske salmer, ${ }^{31}$ har anbefalingen været begrundet med, at det episke stof fra Bibelen gjorde salmerne levende og ikke, at det var vers som genre, der havde en positiv pædagogisk effekt.

"At man lærer lettere Vers end ubunden Stiil, det er, saavidt jeg veed, den første Bemærkning om Vers, jeg har læst". ${ }^{32}$ Vers er således først og fremmest nemmere at lære end prosa. Vers er især lette at lære, når de formidles mundtligt: "hvad gode Vers angaaer, da løbe de

27 Se udkast til Grundtvigs anmeldelse af $\mathrm{Chr}$. Molbechs udgave af Rimkrøniken i Nyt Aftenblad 1826, forrest i fasc. 288; efter Toldberg 1954, 47.

28 I Heimdall, 1815.

29 LBK 1828, VII-VIII.

30 SBRK, 146.

31 Artiklen "Hr. Sandsiger!" og sangen "Deilig er den Himmel blaa" (GSV II, 61) står trykt i K. L. Rahbeks ugeskrift Sandsigeren, 10. april 1811; her læst efter US II, 77-82. Se fx Else Riisager (2009, 12 f.) for gennemgang af artiklen ud fra det følgende perspektiv.

32 SBRK, 145. Grundtvigs synspunkter er uoriginale og hentet i hans læsning af ældre litteratur. Fra og med ca. 1600 blev der også på dansk skrevet læredigte med versefødder og enderim, hvis formål var forkyndelse eller folkelig belæring om $\mathrm{f}$. eks. historie eller naturfænomener. 
endnu langt lettere igjennem Øret, end igjennem Øinene", ${ }^{33}$ Den mundtlige formidling er altså ikke bare nødvendig, for at forkyndelse kan påvirke modtagerne, ${ }^{34}$ men Grundtvig mener, at den også af pædagogiske grunde er at foretrække frem for læsning. Vers er dernæst lettere at lære udenad, og man kan dermed nemmere huske det stof, man har lært: "disse Krønike-Riim (...) kan være til Nytte (...) for deri at giemme, hvad man har lært", ${ }^{35}$ og han ønsker at kunne lave "Kundskabs-Vers, som Børnene gad hørt, og jeg gad havt, de skulde huske, naar de graanede". ${ }^{36}$ Vers i rimkrønikens genre har desuden den egenskab, at de er lettere at læse: "til mine Børns Lære-Bøger ønskede jeg helst idel Rim-Krøniker, som give den letteste og livligste BogLæsning." 37

Det lette bliver ofte nævnt med det livlige i samme pennestrøg. I citaterne ovenfor er 'let' lig med 'nemt' modsat svært, men Grundtvig anvender også ordet i modsætning til tungt og trist. Når et undervisningsmateriale er sådan, at børnene gider høre eller læse det, skaber det liv, munterhed og interesse, og det bliver let for dem at tilegne sig stoffet. Undervisningen bliver livlig. Ved udvælgelsen af digtene til Krønike-Riim skriver han, at "Livlighed [er] Hovedsagen". ${ }^{38}$ I fortalen og indledningen til den poetiske universalhistorie angiver han i slutningen, at det, at digtene er livlige, var vigtigere for udvælgelsen af dem, end om de eventuelt kommer i konflikt med bogens kundskabsmeddelende hensigt. Det livlige havde også førsteprioritet $\mathrm{i}$ forhold til, om digtene ud fra genrebetegnelsen historiske digte kunne stå for en æstetisk kritik. "Alt hvad jeg herom kan sige, er, at det skal være mig omtrent det Samme, hvorledes man bedømmer Bogen, naar man kun vil benytte hvad man finder brugbart". "For de bibelhistoriske digtes vedkommende er pædagogikken underordnet den forkyndende hensigt, men også for denne genre er det lette og livlige vigtige kriterier.

Til disse hører også det levende, som han finder i den historiske fortælling. I et udkast til fortalen til bibelhistorien ønsker han at efterlade næste generation "en Bog, i hvis Rim deres Børn kan bære al deres christelige Kundskab, let som en Fjer, men levende og fri som

Ibid.

34 Jf. at han i foråret 1827 bliver klar over, at "Troen kommer ved at høre, høre 'det Troens Ord, som vi prædike'" (Thodberg et al. 1983, 243; Grundtvig henviser i citatet til Rom. 10,8).

$35^{\circ} K R 1829$, XIX.

36 SBRK, 145.

37 LBK 1828, VII.

$38 K R 1829, \mathrm{XX}$.

39 Ibid. 
Fuglen i Luften!" ${ }^{40}$ For Grundtvig fremkommer det levende i genrer, der $\mathrm{i}$ episk fortælling først og fremmest gengiver historiske fakta $\mathrm{i}$ poetisk form. Det er det, Grundtvig forstår ved det historisk-poetiske. I artiklen i Sandsigeren fastslår han, at Bibelen i hovedsagen består af fortællende beskrivelser af "Mænd og Tildragelser", og hans ideal for den digteriske gengivelse er sange, der indeholder "levende Billeder af Jesu og de hellige Mænds Liv". ${ }^{41}$ Samme sted fremhæver han den historiske, det vil sige bibelhistoriske, salme for at indeholde disse genretræk. I citatet fra fortalen anbefaler han igen den historiske salme, fordi den formidler kristendommen til børn på en ubesværet og levende måde: "at lade Børnene tidlig begynde og seent holde op at lære historiske Psalmer, som er et af de ypperste Midler til at indprænte dem Christendommen blidelig, levende, og uforglemmelig!" ${ }^{42}$ Tilsvarende sammenkædning af det levende og de historiske salmer ses for eksempel i hans beskrivelse af Kingos historiske salmer, som han sætter meget højt. Han pointerer: "Kingo har sin Styrke i en levende Opfattelse og høitidelig Fremstilling af Bibel-Historien". ${ }^{43}$ Ved at bruge den historiske salme med dens poetiske og episk fortællende træk føler man ikke noget direkte savn, men Grundtvig forestiller sig dog noget endnu bedre: "Føleligt vil Savnet [af en bibelsk rimkrønike] heller ikke være, naar vi bruge vore christne Forældres prøvede Huus-Raad: at lade Børnene tidlig begynde og seent holde op at lære historiske Psalmer".

At formidle det lette, livlige og levende i fortællinger på vers til undervisningsbrug tror Grundtvig bedst at kunne gøre i rimkrønikens genre, hvad enten stoffet er historisk eller bibelhistorisk. Den danske Rimkrønike består jo af historiske rim, der hver for sig lader en dansk konge fortælle i jeg-form om sig selv og vigtige begivenheder i sit og folkets liv. Om Krønike-Riim skriver Grundtvig, at man ved hjælp af dem kan "føres til nærmere Bekiendtskab med de mærkværdigste [mest bemærkelsesværdige] Mænd og Folke-Færd", og han betoner børnenes mulighed for indlevelse i store begivenheder og indflydelsesrige personligheder. ${ }^{44}$ På samme måde er det hans forestilling, at

\footnotetext{
40 Grundtvig-arkivet, fasc. 146.8.b.; her citeret efter Bugge 1978, 44.

41 US II, 78; jf. note 31.

42 LBK 1828, VIII.
}

43 Fra Grundtvigs anmeldelse af "Psalmer og Aandelige Sange af Thomas Kingo", samlede og udgivne af P.A. Fenger, 1827, trykt i Theologisk Maanedsskrift, 1828, 1-36, her 32.

44 Eleverne vil få "langt bedre Beskeed om de store Handlinger og Giernings-Mænd i Tidens Løb, og med anderledes Deeltagelse i MenneskeSlægtens vidunderlige Levneds-Løb”. KR 1829, XIX f. 
han i bibelhistoriske rim kan skabe levende fortællinger om Jesus og de hellige mænds liv.

Når Grundtvig foretrækker krønikerim frem for historiske salmer, kan det ses som et tegn på, at selv om det forkyndende vægtes højest, er de didaktiske elementer ved at fă større betydning for ham end tidligere. Dette svarer til hans begyndende teologiske overvejelser om sondringen mellem kirke og skole eller mere specifikt i vores sammenhæng mellem det forkyndende til tro og det kundskabsmeddelende. Grundtvig vil meget gerne lave "Kundskabs-Vers", dvs. læredigte, på det bibelhistoriske område: "Men det har hidtil været min Sorg, at jeg ikke kunde hitte paa at gjøre Kundskabs-Vers, som Børnene gad hørt, og jeg gad havt, de skulde huske, naar de graanede". ${ }^{45}$

\section{Undervisningsmaterialer til kristne børn og lægmænd}

Bibelhistorien og krønikerimene er lærebøger, og det skulle studierne også have været, men blev kun til et første strandet forsøg. Grundtvig ønsker "at gjøre gode Rim-Krøniker til Skole-Brug" med "KundskabsVers" ${ }^{46}$ men han ved også, hvor svær en opgave han stiller sig, for "en god Lære-Bog er et Mester-Værk". ${ }^{47}$ Når det drejer sig om en bibelsk rimkrønike, skærpes kravene yderligere til hans digteriske og pædagogiske evner, og behandlingen af det religiøse stof kræver desuden fingerspidsfornemmelse og veneration.

Angående udarbejdelse af undervisningsmaterialer noterer han, at en lærebog stadig kan forbedres, ved at man laver "mange maadelige Forsøg" og erfarer, hvad der virker i praksis. ${ }^{48}$ Han er også opmærksom på vigtige teoretiske kriterier, der gælder for lærebogsmaterialer til børn. Præsentationen af stoffet skal afpasses efter modtagernes forudsætninger, både hvad angår viden: "da Bogen [dvs. bibelhistorien] i sin forrige Skikkelse forudsatte for meget hos de Smaa, og gav dem for lidet", 49 og modenhed, da det var en fejl hos tidligere generationer at ville gøre "deres umyndige Børn (...) skrift-kloge, før de havde Forstand til at blive det". ${ }^{50}$ Mængden af stof skal tilpasses efter samme hensyn. Børnene skal således ikke kende hele Bibelen, som det var tilfældet tidligere, og man vil derved undgå "den skadelige eller dog unyttige Bibel-Stivhed hos de Christnes Børn". ${ }^{51}$ Han er dog
SBRK, 145.
SBRK, $145 ; 146$.
LBK 1828, VI.
Ibid.
$L B K 1828, \mathrm{~V}$.
$L B K 1828$, VI.
$L B K$ 1828, VII. 
helt klar over, hvor svært det er at finde og videregive den rette selektion af stoffet i forhold til modtagerne. Man kan forestille sig, at han også har sine personlige erfaringer med konfirmandundervisningen i tankerne, hvor hans krav til faglighed og elevernes modenhed var for store. ${ }^{52}$

Bibelkrøniken og studierne skal anvendes ved kristendomsundervisning af børn og ved konfirmandundervisning. Lærebøgerne og studierne er skrevet til brug ved undervisningen af hans sønner Johan og Svend, født 1822 og -24, og andre børn, der typisk bliver undervist hjemme af forældrene eller en huslærer. ${ }^{53}$ En liden Bibel-Krønike for Børn og Menig-Mand, 1828, har tilegnelsen: "Christelige Forceldre og Børn kiærlig tilegnet i Herrens Navn", ${ }^{54}$ og som allerede nævnt har studierne samme målgruppe. Rimene i "Studier til en bibelsk Rimkrønike" er tænkt brugt til undervisning i kristendomskundskab af børn i den, må vi formode, almindelige skolealder, det vil sige børn i aldersgruppen 7-14 år, der ifølge skolelovene fra 1814 er underlagt undervisningspligt. Menigmand er lægmanden, der ikke er teologisk uddannet, og en troende forælder eller huslærer, der forestår undervisningen i hjemmet, kunne eventuelt høre til denne gruppe. Om Grundtvig også ønsker, at undervisningsmaterialerne skal bruges i private skoler og i det offentlige skolevæsen, siger han ikke noget om i disse kilder.

Hvad angår metode for undervisningen, er det Grundtvigs mål, at børnene skal tilegne sig kristendommen "blidelig, levende, og uforglemmelig!" ${ }^{55}$ Det gøres bedst ved, at det kundskabsmæssige indhold bliver videregivet til børnene i gode vers, som de hører og lærer udenad. At mundtlighed i formidlingen af kristendommen er blevet vigtig for Grundtvig, ses også af hans overvejelser i et udkast til fortalen: "Kun i det mundtlige varme Ord er Lyset levende, og hvor det ikke følger med de gudelige Bøger, der er disse kun Pine-Bænke for de Smaa". ${ }^{56}$ Versene skal høres og siges af børnene, men kundskaben skal også forklares mundtligt af læreren, sådan at hans tro på

52 Om Grundtvigs krævende konfirmationsforberedelse før 1824, se Høirup 1962, $61 \mathrm{ff}$.

53 "Thi naar man har Børn, kan man kalde sig selv til Skole-Mester, hvad Øieblik, man vil" (SBRK, 145); "i Grunden har jeg kun skrevet dem [krønikerimene] for mine egne Børn og for deres, der troe som jeg: at Historien giver den sande Menneske-Kundskab" (KR 1829, III). Jf. bl.a. udredningen i Bugge 1978, 36-53.

$54 \quad L B K 1828$, III.

55 LBK 1828, VIII.

56 Fasc. 146. 8. b, $36 \mathrm{v}$; her efter Bugge 1965, 239. 
det glade budskab skinner igennem. De pædagogiske hensyn og den forkyndende hensigt går her op i en højere enhed.

Det konkrete forløb af undervisningen i kristendomskundskab kunne ligne den metode, Grundtvig beskriver i indledningen til Krønike-Riim. Bogen til brug ved undervisning i historie "er beregnet paa en Lære-Maade, der ikke er den sædvanlige". ${ }^{57}$ Først giver læreren ved hjælp af landkortet og et historisk kort en præsentation af stederne for de vigtigste verdenshistoriske begivenheder med udgangspunkt $\mathrm{i}$ Middelhavet og Østersøen. Når børnene har lært det, fortsætter læreren med et grundrids af verdenshistorien. Den geografiske og historiske beskrivelse er mundtlig og sker på "det Korteste og Enfoldigste". Dernæst skal krønikerimene benyttes, "deels for deri at giemme, hvad man har lært, og deels for derved at føres til nærmere Bekiendtskab med de mærkværdigste Mænd og Folke-Færd!". ${ }^{58}$ Til det formål er der to slags digte. Den ene er meget ligetil og skal bruges til at understøtte hukommelsen. Den anden nævner forhold, som børnene ikke kender på forhånd, og er beregnet til at skærpe nysgerrigheden og lærelysten hos eleverne, der kan læse sig til en uddybende forklaring i anmærkningerne bag i bogen.

Bibelkrøniken og studierne er også lagt an på at blive anvendt $\mathrm{i}$ konfirmationsforberedelsen. I disposition og indhold er bibelkrøniken en indføring $\mathrm{i}$ menighedens historie og fællesskab omkring ordet og sakramenterne og svarer derved til et ændret indhold af konfirmationsforberedelsen fra 1824. Selve synet på konfirmationen er skiftet fra, at den unge med Guds hjælp bekræfter sin dåbspagt til, at den unge "bekræftes i dåbens pagt", hvor det er Gud, der bekræfter dåben. Konfirmationen er nu en "indlemmelse i Jesu Kristi menighed". Hvor Grundtvig i konfirmationstalerne lagde vægt på den unges løfte og forsæt, taler han $\mathrm{i}$ foråret $1824 \mathrm{om}$ dåbens gave og håbet, som sakramenterne giver, om at få del i menighedens himmelske fællesskab. ${ }^{59}$ Ligesom ved bibelkrønikens pædagogiske anlæg tager han i konfirmandundervisningen nu langt mere hensyn til de unges intellektuelle, følelsesmæssige og religiøse udvikling. Ændringen i konfirmationsforberedelsen viser, at Grundtvig har indset, at selv om læreren er troende, fungerer undervisningen ikke, hvis ikke undervisningsmetoderne svarer til elevernes modenhed og naturlige udviklingstrin.

I det følgende citat sammenfatter Grundtvig i billedet af kirkebygningen forholdet mellem dåb, oplæring i frelseshistorien i KirkeSkolen og de troendes fællesskab:

\footnotetext{
$57 \quad K R 1829$, III f.

$58 K R 1829, \mathrm{XIX}$

59 Citaterne er fra konfirmationstaler, se Brandt 1877, citeret efter Høirup $1962,65 \mathrm{ff}$.
} 
thi ved Kirke-Døren (...) staaer Døbe-Funten, hvor den Indtrædende maa bekiende sig til Tro paa det evige Liv (...) og annammer derfor med Daaben det kirkelige Vidnesbyrd, at saasandt han var en ærlig Mand, der ikke sagde Andet, end hvad han troede, da er han nu gienfødt til et Guds Barn med Arve-Ret til det evige Liv. Med dette Vidnesbyrd henvises den Nyfødte til Kirke-Skolen, som nødvendig danner Midten i Herrens Huus, hvor Barnet skal oplæres og optugtes, saa han (...) lærer, ved Hørelse og Læsning, eller dog ved en af Delene, at kiende Guds Huusholdning paa Jorden og Hans Førelser med Menneske-Slægten, fra Begyndelsen til Tidens Fylde, og fra den til Enden. (...) Endelig staar Alteret, som Herrens Bord, i Choret, som det Allerhelligste, og dertil indbyder Kirken de Voxne, som have lært i Skolen, hvad det vil sige paa Aandens Sprog, at sidde tilbords med Abraham, Isak og Jacob i Himmeriges Rige. ${ }^{60}$

At skrive digte til en bibelsk rimkrønike faldt som nævnt Grundtvig svært i 1828. De rim, han lader trykke i studierne, har ikke en kvalitet, som han synes, er høj nok til, at børnene skal lære dem udenad og huske i alderdommen. Men rimene kan alligevel benyttes i undervisningen. Vers i rimkrønikens genre har jo heldigvis også den egenskab, at de giver "den letteste og livligste Bog-Læsning", og han finder de udgivne rim "gode nok til at læses for en Gang eller to". 61

\section{"Kain pløied rask i Vaar"}

“Kain og Abel” (GSV II, nr. 6) er et eksempel på, hvordan Grundtvig efter 1824 i praksis formidler et bibelhistorisk stof til kristne børn. Da digtet blev trykt første gang i "Studier til en bibelsk Rimkrønike" i 1828, var GSV II, nr. 6 og 7 et sammenhængende digt med titlen "Patriarcherne". I de følgende udgaver ændrede han ikke i de strofer, som GSV II, nr. 6 består af, og da stroferne tydeligvis danner en helhed, vil kun denne del af digtet blive behandlet mere indgående.

Specielt i digte med stof fra det Gamle Testamente, der jo har et jødisk univers, er det interessant at se, på hvilken måde Grundtvigs erklærede kristent forkyndende hensigter slår igennem i praksis. Udeladelser og tilføjelser $\mathrm{i}$ forhold til forlægget, 1 Mos 4,1-16, ${ }^{62}$

60 Fra Om Christendommens Sandhed, 1826; citeret efter Holmgaard 1951, 11-12.

61 SBRK, 146.

62 Læst efter Biblia, reviderede 13. oplag fra 1787, der er Grundtvigs foretrukne bibeludgave. I hans eksemplar er NT næsten ikke anvendt, mens Chr. Ludwigs, der har ejet Grundtvigs bibel, fortæller, at "han aldrig [blev] så stiv hebraist, at han brugte den gammeltestamentlige grundtekst til sin opbyggelseslæsning (...) G.T. er slidt og pløjet, især salmerne og profeterne" (Ludwigs 1919; jf. Bugge 1965, 141). Grundtvigs forlæg til de nytestamentlige digte har 
fortællerforholdene, især vekselvirkningen mellem en implicit og en alvidende fortæller, og endelig forekomster af den firefoldige teksttolknings forskellige niveauer vil være $\mathrm{i}$ fokus.

Fortællingen i digtet er berettet i episk præteritum af et ikkeeksplicit jeg. Sidste strofe er i præsens, 'altid'. Digtet er opdelt i to afsnit: str. 1-6: introduktion og offer og str. 7-14: drab og forbandelse, og det afsluttes med epilog i str. 15. Afsnittene er markeret af gentagelsen af linjen "Abel gik og vogted Faar" $(1 \circ \mathrm{og} 7)$. Digtets disposition følger forlæggets. Således har både digtet og forlægget i første afsnit en kort fortalt handling med beskrivelse og replik, mens begge i andet afsnit har dialog og afrunder med kommentar og beretning. De indlagte replikker af Gud og Kain findes omkring det dramatiske højdepunkt $\mathrm{i}$ forløbet og indledes $\mathrm{i}$ begge afsnit af digtet med Guds enslydende anråbelse af Kain (5 og 8). Digtet er således episkdramatisk med enkelte lyriske indslag. Denne form bliver den altdominerende i Grundtvigs bibel- og kirkehistoriske salmer og sange.

I digtet blotlægges to mennesketyper, og deres skæbner forstås som en direkte følge af deres forhold til Gud. Stoffet i 1 Mos 4, 1-2, der handler om Kain og Abels fødsel, er udeladt i digtet. Derved underbetones slægtskabet med Adam og Eva, ${ }^{63}$ mens udeladelsen indirekte fremhæver digtets tema med de to mennesketyper, Kain af "den Onde" (str. 14) og Abel, der med sin af digteren tilsatte søde dødssøvn og paradishåbet står for det gode (str. 15). Digtet tilføjer str. 15 om Abels paradishåb, der udbygger temaet om den gode Abel. Ændringerne viser en generel tendens i digtet, hvor udeladelse og tilføjelse koncentrerer digtet om dets tema samtidig med, at modsætningerne skærpes. Budskabet i digtet bliver derved tydeligere end forlæggets.

På det 1. (historiske eller bogstavelige) niveau præsenteres Kain og Abel i første strofe som henholdsvis agerdyrker og fărehyrde. Kain skildres som rask i det og med interesse for det nærværende, timelige, mens Abel sindigt går og funderer over tilværelsens evige perspektiver. Det er den alvidende fortæller, der med et tillæg til forlægget beskriver brødrenes tanker med de negativt og positivt ladede udtryk "Næste" og "Bedste". Specielt det sidste udtryk og den indbyggede

således været den originale græske tekst, mens det til de gammeltestamentlige digte sandsynligvis til og med dette tidspunkt har været den autoriserede danske bibeloversættelse. Fra 1830'erne brugte Grundtvig sideløbende eller overvejende Septuagintas græske tekst ved sin anvendelse af gammeltestamentligt stof (jf. Thodberg 1998).

631 Mos 4,1-16 kan i den gammeltestamentlige sammenhæng ses som en uddybning af Adams og Kains slægtsregistre på linje med 1 Mos 4,23-24. 
vurdering kan kun forstås af en læserperson eller en real modtager, der er fortrolig med en kristen kulturtradition. ${ }^{64}$

Vurderingen af personerne uddybes i de følgende strofer. I digtet ofrer Abel "Dæggelammet" (str. 3), dvs. et lam, der ikke har fået die, men som han selv har opfodret og derfor holder særligt af..$^{65}$ I 1 Mos 4,4 ofrede han "af sin hiordes første affødning", der er en neutral betegnelse for de førstefødte dyr. Fortælleren har således i digtet gjort Abels offer større, ved at han ofrer noget, han har personlige følelser for. I modsætning til forlægget bliver Abels offer derfor også større end Kains. I forlængelse heraf beskriver forlægget kun, hvad der sker, mens fortælleren i resten af strofen fortæller om de indre følelser, personerne udfører deres handlinger med. Ved hjælp af den alvidende fortæller sker der således ligesom i første strofe en psykologisering i digtet. Kains tak for årets afgrøde er udtryk for et overfladisk, uengageret forhold til Gud, mens Abels er lidenskabeligt. Abels offer til Gud er på denne måde ikke bare af større følelsesmæssig værdi end Kains, men også udført med den rette indstilling. ${ }^{66}$

Digtet tilføjer en årsagsforklaring på Guds forskellige modtagelse af de to brødres ofring. I 1 Mos 4,4-5 står forskelsbehandlingen uforklaret, den konstateres blot. ${ }^{67}$ I digtet er brødrene selv skyld i deres forskellige livsvilkår: Kain nærer ikke de rette ægte og dybe følelser i sin tak til Skaberen (str. 1-3), dvs. at han ikke accepterer de givne vilkår, hvorved hans tro er vaklende. Mens bibelstedet kan opfattes som et eksistentielt udsagn om de menneskelige grundvilkår, gives der i digtet en psykologisk forklaring: Det uforklarlige får en årsag, som tilmed - tilsyneladende - ligger hos mennesket, dvs. at mennesket har mulighed for at påvirke sin egen skæbne. Desuden opnår digtet ved at placere skylden hos mennesket så at sige at redde det kristne dogme om Guds retfærdighed, mens forskelsbehandlingen af de to brødre i forlægget kan opfattes som dybt uretfærdig. Digtets præsentation af stoffet kan derfor lettere end forlæggets bruges i en holdnings-

64 Det er nærliggende at associere til søstrene Martha og Maria, hvor Maria valgte den gode del (Luk 10,38-42).

65 Jf. udtrykket "kæledægge".

66 Jf. "men Abel var taknemmelig i sit Hjerte, og det var Kain ikke, og Gud, som eier Alt og trænger ei til Gaver, Han seer kun paa Hjerte-Laget, derfor havde Han Behag i Abels Offer, men ikke i Kains." (LBK 1828, 5-6). Jf. ligeledes "Kain dræbte sin Broder, hvis Offer Gud havde optaget naadigere, fordi det frembares med et renere Hierte" (VK 1812, i US II, 188). Se også Hebr 11,4: "Formedelst troe ofrede Abel Gud et større slagt-offer, end Cain, formedelst hvilket han fik vidnesbyrd, at han var retfærdig, i det Gud vidnede om hans gaver; og ved den taler han endnu, alligevel han er hendød."

67 Jf. 2 Mos 33,19: "Og jeg vil være den naadig, som jeg vorder naadig, og forbarme mig over den, hvilken jeg forbarmer mig over." 
bearbejdende og forkyndende hensigt. Årsagsforklaringen bliver en del af det moralske tolkningsniveau i digtet.

Personernes forhold til Gud får konsekvenser. Abel belønnes med, at Gud udmærker hans ofring (str. 4), og at han efter døden befinder sig i en behagelig ventetilstand med håb om evig frelse (str. 15). Kains første fejl derimod efterfølges af en række andre: vrede, misundelse, overhørelse af advarsel (str. 4-6), hyklerisk attitude, brodermord (str. 7), løgn, mened, frækhed (str. 9), og mangel på anger og bod (str. 14). Som følge af brodermordet og understøttet af det øvrige synderegister forbander Gud Kain, og jorden bliver tilmed forbandet på grund af ham (str. 11). Han bliver på det første, historiske niveau sat uden for den menneskelige, af Gud skabte orden:

1. Han bliver landflygtig, dvs. udelukket af det sociale fællesskab (str. 13-14);

2. må ernære sig af den vilde natur og ikke den frugtbare agerjord (str. 12, jf. str. 1-3);

3. bliver umenneskelig, gjort til et vilddyr eller udyr i adfærd (str. $11 \mathrm{og}$ 13);

4. bliver på det indre plan utryg og er ude af balance (str. 12);

5. søger ikke at komme ind under ordenen igen (str. 14).

Også i disse strofer af digtet sker der mindre ændringer af stoffet blandt andet ved udnyttelse af de tekniske muligheder, der ligger hos den implicitte fortæller. Ændringerne medfører samlet set, at forlæggets gammeltestamentlige univers bliver kristnet.

Handlingerne er mere radikale i digtet end i forlægget. Tendensen ses tydeligt ved, at Guds straf af Kain er hårdere. ${ }^{68}$ I forlægget mildner Gud forbandelsen ved at sætte et tegn på ham, der beskytter ham mod at blive slået ihjel. ${ }^{69}$ Forlægget slutter: "Saa gik Cain ud fra HERRENS ansigt, og blev i det land Nod, østen for Eden" (1 Mos 4,16). Han overlever altså fysisk, men må opholde sig i landflygtighedslandet, dvs. kaos, og specifikt det sted, hvor han ikke kan

68 Som et andet eksempel kan nævnes, at Kain i digtet dræber sin bror "Under Vennetale" (str. 7). I 1 Mos 4,8 står der: "Og Cain talede med Abel sin bror; og det hendte sig, der de vare på marken, da opstod Cain imod Abel sin broder, og ihielslog ham". Forlæggets neutrale betegnelse 'tale' er endda i andre oversættelser gengivet med "yppe kiv" o. lign., da den hebraiske overlevering er usikker. I forlægget er mordet heller ikke kædet direkte sammen med samtalen. Forbrydelsen bliver således mere grel i digtet, da Kain her tilmed opfører sig slesk og hyklerisk.

691 Mos 4,13-15. 
møde Jahve i kulten. ${ }^{70}$ I digtet er kainsmærket udeladt, og beskrivelsen af Kain ender ikke med, at han lever, men at han går "til Grunde" (str. 14). I den kristne kulturtradition er der til dette udtryk konnoteret ikke bare, at han dør, men at han ender i helvede, Satans eller den Ondes rige. ${ }^{71}$ Helvedesforestillingen underbygges ved, at Kain betegnes med metaforen "fuleste Uhyre" (str. 11) og at det fordærvede umenneske som et udyr farer af sted og gemmer sig (str. 13). Han bliver brændt som af ild og hviner, og Gud advarer ham imod, at synd "Dages brat til Pine" (str. 5). Kain kommer i en helvedes pine både i levende live og på dommens dag. ${ }^{72}$ Den implicitte fortæller konkluderer på hans levnedsløb, at "han var af den Onde" (str. 14), dvs. tilhører Satan. Med denne konklusion er sandheden om Kain tolket ud fra hentydninger til det 2. typologiske niveau i den firefoldige teksttolkning, og han ses i et overordnet frelseshistorisk perspektiv. Derimod er der "ingen Pine" i "Haabets Lund" (str. 15), ${ }^{73}$ hvor Abel befinder sig, og ilden er positivt konnoteret, når "Abels Hjerte flammed" (str. 3) i brændende hengivenhed for den gode Gud, som han tilhører (str. 10;15). ${ }^{74}$

Den større radikalitet i digtet svarer til en skærpelse af forskellene på de to mennesketypers forhold til Gud, og vi ser en forstærkelse af den negative og positive vurdering af dem hos fortælleren. Årsagen til, at Kain ikke făr kainsmærket til beskyttelse, ligger i, at han i digtet ikke fortryder (str. 14). I 1 Mos 4,13 siger Kain: "Min misgierning er større, end jeg kand bære". Ved at bruge ordet "misgierning",75 indrømmer Kain at have handlet forkert og udviser derved en del af en angergiven holdning. Ved at udelade denne indrømmelse i digtet skærpes den negative vurdering af Kain, samtidig med at fortælleren indirekte hentyder til, hvordan en kristen ved at angre og gøre bod i en lignende situation kan forsone sig med Gud. Fortælleren påpeger da også meget pædagogisk, hvordan Kain "Uden Anger, uden Bod" går fortabt (str. 14). Ændringen, der henviser til den

\footnotetext{
70 Jf. fx Mogensen 1972, 35.

71 'Gå til grunde' har bibetydningen 'forgå', der i religiøs sammenhæng betyder at 'miste sin salighed, fortabes' (ODS).

72 Versene i str. 5 kan også forstås som en allegori, der siger, at efter syndens mørke, dvs. forbrydelse, kommer en morgen med dagslys og pine, dvs. afsløring og straf.

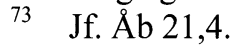

74 Jf. at Jesus i Matt 23,35 regner Abel til de 'retfærdige', dvs. personer der som Noah og Abraham har en livsførelse, der er i overensstemmelse med Guds vilje (Gads Danske Bibelleksikon, 1981, "Retfærdiggørelse", 195).

75 Der er usikkerhed om oversættelsen af den hebraiske grundtekst. I de autoriserede oversættelser fra 1931 og 1992 bruges ordet "straf". Grundtvig anvender dog "misgierning" i $L B K 1828,6$.
} 
rette kristne holdning og adfærd, er på samme måde som den omtalte psykologisering med til at tilføre digtet 3 . niveaus moralske tolkning.

Det tilførte kristne univers, der blandt andet bevirker, at den åndelige tolkning forstærkes på bekostning af den bogstavelige, understøttes af, at Kains ustadighed flyttes fra yder- til inderverdenen: "ustadig og flygtig skal du være på jorden" (1 Mos 4,12) bliver i digtet til mangel på "Sjælero" (str. 12). Ligeledes er Kain i sin frie tilværelse i ørkenen 'ufri' på det indre plan, idet han drives af misundelse (str. 6). Stedet giver associationer til den centrale beskrivelse, Paulus har i Romerbrevet af, hvorledes mennesket enten træller under synden eller loven i modsætning til under retfærdigheden eller nåden. I digtets sprogbrug er det omskrevet til, at mennesket enten tilhører "den Onde" eller Gud. Stedet peger også hen på Luthers forståelse af mennesket som enten bundet til og dermed fri i Kristus eller bundet til synden, sådan som det er udfoldet i "Om et kristenmenneskes frihed" ${ }^{76}$ Digtet åbner sig således også her mod betydningsfulde elementer i en kristen, specifikt luthersk, tolkning af de menneskelige livsvilkår, og hentydningerne understøtter det 3. tolkningsniveau.

Vi har været på sporet af, at der er sammenfald mellem Guds vurderinger, holdninger og sprogbrug $\mathrm{og}$ fortællerens. Derved får fortælleren tilført ekstra autoritet. Fortælleren bifalder blandt andet Kains fordømmelse (str. 9-14) og Guds handling i strofe 4. Når Gud taler med Kain, bruger han for eksempel skældsordene "Løgner" (str. 10) og "fuleste Uhyre" (str. 11). Tilsvarende omtaler fortælleren Kain som "den Fule" (str. 13) og "Skarnet" (str. 9), ligesom de begge bruger parafrasen "Pine" (str. 5;15). Der er også andre lighedspunkter. Hvor Gud demonstrerer de guddommelige attributter almagt og alvidenhed, er fortælleren alvidende, og når Gud er fremstillet særdeles antropomorft med replikker og skældsord, falder det fint i tråd med den implicitte fortællers mange positivt og negativt konnoterede ord i beretningen og forfatterkommentarerne. Forfatterpersonen formidler sit budskab så pågående og entydigt, at der endog forudsættes en identisk holdning mellem Gud, fortælleren og læserpersonen, som kan have en stærkt holdningsbearbejdende virkning på en real modtager.

Som Gud i fortællingen agerer over for Kain og Abel, stiller fortælleren i digtet sig til læserpersonen, og autoritetsforholdet imellem dem er som mellem lærer/forældre og børn. Da Gud irettesætter Kain, føler fortælleren sig således berettiget til i en kommentar at påpege over for læserpersonen, at Kain burde skamme sig (str. 4). Den vurderende sproghandling er så stærk, at den nærmer sig det handlingsregulerende over for en real modtager med læserpersonens

76 Rom 6 og Martin Luther, "Om et kristenmenneskes frihed" i Nøjgaard 1962, 282 ff, spec. 294. 
træk, hvis vedkommende skulle komme i en lignende situation. Når fortælleren tilsvarende understreger, at Kain går til grunde uden anger og bod (str. 14), ligger der implicit i udsagnet en vurderende sproghandling, der siger, at han burde have angret sin onde handling og bedt om tilgivelse af Gud, på samme måde som et barn skal angre sine fejltrin og bede om tilgivelse af sine forældre, når det har gjort noget forkert. Også den tautologiske tilføjelse til "din Broder", "Sønnen af din Moder" (str. 8), appellerer følelsesmæssigt til børn. Børn vil umiddelbart fornemme, hvor forfærdelig Kains forbrydelse er, for hvad er værre for et barn end at gøre sin moder ondt?

Fortællerens tendens til at udlægge handlinger og sindstilstande, som for eksempel ved psykologiseringerne og årsagsforklaringerne, er med til at underbygge, at læserpersonen er et barn. I samme retning virker tydeliggørelsen af temaet og den større radikalisering og skærpelse af forskellene på de to mennesketyper i digtet. Tydeliggørelsen findes også i sprogbrugen, hvor der er eksempler på eksplicitering: "Løgner" og "Udaad" (str. 10) over for forlæggets "Og hand [Gud] sagde: Hvad haver du gjort?" (1 Mos 4,10), på specificering: "Avind" (str. 6) over for "synd" (1 Mos 4,7) og på konkretisering: "Dæggelammet" (str. 3) over for "af sin hiordes første affødning" (1 Mos 4,4) og "Klinte, Byg og Hvede" (str. 12) over for jordens "formue" (1 Mos 4,12). I samme retning peger, at digtets ordvalg og syntaks som helhed er jævn og enkel, ${ }^{77}$ ligesom billedbrugen gennemgående er konventionel og/eller hentet fra forlægget. Udlægningerne, forklaringerne og tydeliggørelserne gør det mere forståeligt, hvorfor det går brødrene, som det gør, samtidig med at det via læserpersonen påvirker en real modtager til at vurdere handlingsforløbet på samme måde som fortælleren, så en real modtager kan tilegne sig de samme holdninger og tænkemåder.

Selvom den primære læserperson er et barn, indeholder digtet også elementer, der appellerer til den lærer eller de forældre, der underviser eller vejleder barnet i kristendomskundskab. De afsæt og allusioner, der findes i digtet, til central kristen og specifik luthersk dogmatik kræver mere modenhed og større viden, end man normalt finder hos et mindreårigt skolebarn. Det gælder den fremanalyserede årsagsforklaring og hentydningerne til dogmet om Guds retfærdighed og Luthers opfattelse af et kristenmenneskes frihed. Disse tankegange er dog ikke mere specielle, end at de hører med til en almindelig voksen persons og dermed en lægmands viden om kristendommen. At digtet også

\footnotetext{
77 Man kan bl.a. notere sig, at stilen i de netop anførte eksempler gennemgående er lavere i digtet end i forlægget. Digtet indeholder en del eksempler på ellipse (str. 5,4;6,4;9,4) og inversion (str. 9,1;10,2;13,3), der understreger det lidt følelsesbetonede og talesprogsagtige.
} 
rummer dette dybere indhold for en voksen, viser det som en forløber for senere, fremragende børnelitteratur, der som H. C. Andersens eventyr netop er skrevet sådan, at en voksen gerne vil lytte med. ${ }^{78}$

Derudover er læserpersonen et barn, hvem et landligt og dansk miljø ikke er fremmed. Digtets rum har ikke noget specifikt mellemøstligt præg, men kan udmærket være det danske bondeland, hvor der gror klinte, byg og hvede (str. 12), og hvor man vogter får i solnedgangen (str. 7). Abels sindighed (str. 1), gudsfrygt (str. 3) og let sværmeriske beskuelse af solnedgangen kan også udmærket identificeres med det gængse, positive billede af den danske bonde. ${ }^{79}$ Den hjemlige, landlige atmosfære understøttes af digtets visestil, der på flere punkter giver allusioner til folkevisen, ${ }^{80}$ der jo på digtets affattelsestidspunkt var udbredt og skattet især på landet. Hele det kristne univers bidrager ligeledes $\mathrm{i}$ høj grad til fornemmelsen af at befinde sig i et hjemligt miljø. ${ }^{81}$

Som digtets rum overskrider også digtets tid det historiskgeografiske univers. Fortællingen, skildret i præteritum, foregik engang, men dens virkninger gælder også i nutiden og ind i evigheden. Derfor er der i den tilføjede epilog brugt præsens, 'altid':

Abel slumrer sødt i Løn,

Gud ei glemmer Sine,

78 H. C. Andersen udgav sine første Eventyr fortalte for Børn i 1835. "Men, fortsætter Andersen selv, naar jeg tænkte mig mine Eventyr fortalte for Børn, forestillede jeg mig tillige, at Fader og Moder stod hos, og de skulde have noget for Tanken" (Andersen 1924, 547). Andre eksempler er Lewis Carroll (1865), Alice's Adventures in Wonderland, A. A. Milne (1926), Winnie-thePooh og Astrid Lindgreen (1963), Emil i Lönneberga.

79 Jf. den positive vurdering af Seth, erstatningen for Abel, og hans slægt over for den negative af Kains slægt, der er byboere, i de efterfølgende strofer, det senere selvstændige digt "Stamfædrene", GSV II, nr. 7, str. 1 og 911 over for str. 2-3. Allerede i $V K 1812$ udvikler Grundtvig sine positive og negative vurderinger af det frie hyrdeliv på landet over for bylivet og sætter det i relation til gudsforholdet (US II, 188-191).

80 De mest iøjnefaldende fællestræk er den enkle, episk-dramatiske stil, de korte, firelinjede strofer, vekslen mellem beretning og dialog, tautologien og eksemplerne på let arkaiserende sprogbrug ("Banesaar" (str. 7), "Løn" (str. 15)), evt. kombineret med ellipse ("faar det beesk at finde!" (str. 6, jf. også str. 4 og 5). Man kan fx sammenligne GSV II, nr. 6, og "Ebbe Skammelsøn" (DgF nr. 354), der har brodermord som fælles motiv.

81 At Grundtvig inddrager det hjemlige miljø, ligger i forlængelse af en tendens i oplysningstidens pædagogik, den såkaldte 'lokalisering', dvs. tilpasning til barnets velkendte miljø. Allerede i 1804 gav han udtryk for, at han var tilhænger af denne tendens (jf. Bugge 1965, 70). 
Haabets Lund er immergrøn,

Der er ingen Pine! (str. 15)

Den direkte tale i replikkerne er med til at gøre fortællingen nutidig og levende, mens "immergrøn" og udtrykket "Gud ei glemmer Sine" har en tredobbelt tidsbetydning, der forstærker evighedsperspektivet. Det samme er tilfældet med hele udtrykket "Haabets Lund er immergrøn", der både kan opfattes konkret, som en metafor for kirkegården, og abstrakt, som det rum "i Løn", hvor Abel befinder sig. For Abel er ikke kun død, han slumrer sødt, ${ }^{82}$ og da han har det rette forhold til Gud og tror på ham, og da Gud ikke glemmer dem, der tilhører ham, ${ }^{83}$ har Abel del i det kristne evighedshåb, og det er håbet om opstandelse. Udtrykket "Haabets Lund" giver allusioner til paradisets have, som Abel skal vågne op til. Det 4. eskatologiske tolkningsniveau er således antydet til stede. I strofens sidste linje, "Der er ingen Pine!", og indirekte i den anden linje fastholdes modsætningen til Kain og digtets øvige eskatologiske forestilling, helvede.

Men ikke kun for Abel er der håb om genopstandelse og evig glæde, det er der for alle, der tilhører Gud. At Abel slumrer og venter, tyder hen på, at læserpersonen også efter døden skal slumre sødt $\mathrm{i}$ "Haabets Lund" og vente på opstandelsen i Guds rige. ${ }^{84}$

Ud fra sidste strofe kan der opstilles en samlet oversigt over de firefoldige tolkningsniveauer i digtet:

1. historisk niveau: Abel er død

3. moralsk niveau: Opfordring til at tilhøre Gud som Abel

4. eskatologisk niveau: Abel har håb om en evighed uden smerte.

Digtet rummer en kristent forkyndende hensigt, men er ikke kristologisk, da tolkningsniveauets 2 . trin mangler i form af en henvisning til Kristi frelsergerning. ${ }^{85}$ Også i digtets fortælling er der i det gammeltestamentlige univers adskillige forkyndende træk som for eksempel ofringen til Gud og Guds styring af menneskets skæbne. Det kristne univers, dvs. overbygningens 3 niveauer, overskrides ikke, for eksempel retter Kain ikke sin vrede over tilsidesættelsen (str. 4) direkte mod Gud, og han accepterer forbandelsen (str. 13). Det gammeltesta-

82 Jf. Jesu opvækkelse af Jairi datter (Mark 5,21-43, spec. 5,39: "barnet er ikke død, men sover"; jf. "Blomst kan visne", GSV II, nr. 77).

${ }^{83}$ Jf. Es 44,$21 ; 49,15$; Luk 12,6.

84 Der er dog ikke tale om en fuldgyldig figuraltolkning, da der i digtet ikke er hentydninger til det manglende nytestamentlige led, nemlig Jesus.

85 De tidligere næunte hentydninger til det 2 . typologiske niveau med det frelseshistoriske perspektiv er ikke signifikante nok til, at alle 4 tolkningsmåder kan siges at være til stede i digtet. 
mentlige univers modsiges heller ikke, da de eskatologiske forestillinger og troen som det afgørende i Kains og Abels forhold til Gud kun antydes, ikke udfoldes.

Det historiske niveau er fremtrædende i digtet, men det er dog også kundskabsmeddelende, følger i hovedsagen forlægget tæt og loyalt og indeholder i sin dogmatisk-kristne forkyndelse den "Aand", der i fortalen til bibelhistorien er nævnt som en forudsætning for, at det kan bruges til undervisning i en kristen sammenhæng. Fortalens krav om, at formidlingen af "Aanden" eller en kristen holdning også skal være til stede hos forældre/lærer i undervisningssituationen, passer med digtets sammenfald mellem forfatterpersonen, fortællerinstans, Gud og lærer/forældre.

I digtet ligger der også en hensigt om at virke på det socialt almendannende område. Kains dårlige forhold til Gud, hans vantro, fører ikke bare til hans egen fortabelse, men desuden til et dårligt forhold til medskabningen, familien og medmennesket ved den direkte udstødelse af den sociale orden. Uden hensyn til den kristne overbygning advarer digtet på denne måde en læserperson mod at leve som Kain. Påpegningerne af, hvordan man ikke bør opføre sig over for en autoritet med Kain som eksempel, viser i samme retning. Han og hans skæbne fungerer på det etisk almendannende niveau som et negativt forbillede. Konklusionen på digtets tema er, at tro eller vantro i forholdet til Gud er afgørende for menneskets liv både her og hisset.

Appellen til en real modtager, der kan identificere sig med læserpersonen, kan derfor være stærk. Da digtets tid og rum ikke er specificeret, men udmærket kan være et nutidigt anno 1828, dansk og landligt miljø, har digtets moralske aspekt således mulighed for at have stor virkning på en barnlig læser, der tilhører dette miljø. Virkningen vil måske oven i købet blive forstærket, hvis digtet bruges $\mathrm{i}$ en undervisningssituation, således som det er hensigten fra forfatterens side. Derved vil digtets autoritetsforhold spejle sig i den reale verden.

\section{"Studier til en bibelsk Rimkrønike"}

"Kain pløied rask i Vaar" med titlen "Kain og Abel" (GSV II, nr. 6) bliver trykt første gang i "Studier til en bibelsk Rimkrønike" i 1828 som første del af digtet "Patriarcherne", mens resten af stroferne blev senere det selvstændige digt "Stamfædrene" (GSV II, nr. 7). Digtene i studierne, GSV II, nr. 1, 2, 6+7 og 8, er Grundtvigs første systematiske udgivelse af bibelhistoriske digte. Emnerne for hans bibelhistoriske digtning indtil nu har en tilfældig kronologi $\mathrm{i}$ forhold til den frelseshistoriske tidslinje. Rimene i studierne derimod gengiver det 
bibelske stof $\mathrm{i}$ de første dele af urhistorien fra skabelsen til og med syndfloden og står kronologisk. Ifølge Grundtvigs fortale var digtene vragede forsøg på at skrive en bibelsk rimkrønike, der kunne bruges som undervisningsmateriale for børn. Stroferne i GSV II, nr. 6 og 7 får deres endelige form allerede i udgaven fra $1828,{ }^{86}$ mens især GSV II, nr. 1, "Skabelsen", og GSV II, nr. 2, "Adam og Eva", blev en del omarbejdede i udgaverne GSV $\mathrm{II}^{1}$ fra 1839 og GSV $\mathrm{II}^{2}$ fra $1870 .^{87}$

I formen er alle digtene grundlæggende episk-dramatiske med lyriske indslag, men er dog så forskellige i deres udtryk, at de kan inddeles i to grupper, GSV II, nr. 6+7, og GSV II, nr. 1, 2 og 8. De kan også ses i lyset af træk fra samtidens teologiske debat og fra tidens litterære stil.

De generelle træk, der er opsummeret for "Kain og Abel", genfindes i "Stamfædrene". Det gælder forekomsten og karakteren af de firefoldige teksttolkningsniveauer samt den historisk informerende bestræbelse. Målgruppen er stadig børn og deres lærer/forældre. De almendannende træk har dog større vægt i "Stamfædrene".

Indholdsmæssigt beskriver $G S V$ II, nr. 7 to forskellige ætter. Kains æt har kort levetid i deres bykultur, der er fyldt med materialisme, sex, mord og krig. Deres håndværk og musik understøtter og fremhæver stolt og pralende deres levevis. Abels æt gennem Seth lever derimod længe. De er stille, ydmyge og glade for deres hyrdeliv på landet, hvor nattergalene synger (str. 9 og14). ${ }^{88}$ De er "Guds Børnestamme" (str. 11), og efter døden venter de som Abel at få det evige liv "I de grønne Sale" (str. 14). Via citat fra 1 Mos 3,15 om "Kvindens Sæd" (str. 10), der traditionelt er blevet opfattet som en forudsigelse af Jesus, henvises der til, at Jesus er af samme æt som de. En af ætten, Enoch, der var "God for Herrens Øie" (str. 13), optages i Himlen som en præfiguration af Jesu himmelfart.

I sine mange vurderende sproghandlinger bruger den implicitte fortæller ud over negativt og positivt konnoterede udtryk en del faste vendinger og talemåder. Flere af udsagnene er sat ind i en alment moraliserende sammenhæng, der styrker det almendannende sigte i digtet, fx "Ukrud yngler meest paa Jord, / Modnes først og falder" (str.

\footnotetext{
86 Der er dog en enkelt, ubetydelig rettelse i de senere udgaver i GSV II, nr. 7 str. 1.

87 I studierne indeholder GSV II, nr. 1 og 2 en del flere vers end i de senere udgaver. "Skabelsen" har ikke nogen strofeinddeling i 1828-udgaven. For overblikkets skyld vil jeg dog i den følgende gennemgang referere til de senere versioners strofeinddeling og nummerering, hvor det er muligt.

88 Nattergalen indgår hos Grundtvig $i$ et indviklet symbolkompleks og hentyder bl.a. til paradiset og et idealbillede af Danmark (se fx Nyaars-Morgen, str. 120; Toldberg 1950, 272 m.v.).
} 
2), "Stort det skulle være" (str. 3), og "Verdens Børn kan Verden bedst / Føre sig til Nytte" (str. 4). I nogle af udsagnene om Kains æt er der dertil indlejret en snært af ironi og endda hån. Ligesom Kain var morder, hylder Lamech sin forfader ved selv at slå ihjel og prale af sine gerninger $\mathrm{i}$ en sang. Ved sin ætlings forbrydelser og selvtilfredshed får Kain sin løn som morder (str. 5-6). Fortælleren har også en direkte henvendelse til læserpersonen, "Nemt at ihukomme!" (str. 8), som angiver, at stoffet om brødrene Tubal og Jubal er godt lærebogsmateriale.

GSV II, nr. 1, 2 og 8 adskiller sig fra GSV II, nr. 6+7 stilmæssigt, til dels indholdsmæssigt og med hensyn til primær målgruppe. I $G S V$ II, nr. 1, "Skabelsen" tager med det kollektive 'vi' udgangspunkt i vores sansning og undren over jordens mangfoldighed. Samtidig opridses der to forskellige teologiske tilgange til skabelsen. Strofe 1-24 er forberedelse til fremstillingen i str. 25-36 af den bibelske beretning fra 1 Mos 1. Digtet afsluttes med to større afsnit, hvor fortælleren i udlæggende og opfordrende sproghandlinger taler direkte til modtagerne "I Unge", hvorefter han igen gennem det kollektive 'vi' drager læserpersonen med ind i sin entusiastiske beskrivelse af skaberværket. 'Vi'-fortællerens sansning, tanker og udlægning af skabelsen dominerer således klart over gengivelsen at det bibelske stof.

Gennem synet og fornuften oplever og prøver 'vi'et at forstå naturen og mennesket. Da mennesket ikke er almægtigt (str. 7-8), ${ }^{89}$ må der være en skjult Gud, der er skaber og opretholder, og som er alvidende og almægtig (str. 9-10). Skabningen må være et "Værk af den Høie" (str. 9). Gennem øret og menneskets tale eller ord, der stammer et andet sted fra, prøver 'vi'et at forstå, hvor ordet kommer fra (str. 11-22). Svarene på spørgsmålene str. 1-22 findes i str. 23-24, hvor det fastslås, at "Han i det Høie", dvs. Gud, er skaberen og opretholderen, og at vi mennesker har ordet fra ham, dvs. at vi har ordet til fælles med Gud.

En tilværelsestolkning med udgangspunkt i den menneskelige sansning og fornuft lægger op til en forståelse som i naturlig religion, hvis ideer havde stor indflydelse på oplysningstidens danske teologer. $^{90}$ Tidlige tilhængere af naturlig religion mente, at mennesket

89 Med allusion til H. A. Brorsons nælde i "Op! al den ting, som Gud har giort” (str. 2). I Evangelisk-kristelig Psalmebog, 1798, var nælden ændret til "mindste Straa", og Brorson havde ingen særlig betydning som salmedigter i samtiden, heller ikke for Grundtvig. Men i 1823 kom et udvalg af hans salmer i en autentisk, sprogligt let moderniseret form, som indledte romantikkens genopdagelse af forfatterskabet.

90 Jf. Balling og Lindhardt 1979, 152 ff. I Danmark indgik den naturlige religions ideer i mange varianter i de fremtrædende teologers fremstillinger. 
gennem fornuften kunne slutte sig til, at der som det første af fem hovedpunkter findes en højeste guddom. ${ }^{91}$ Fortælleren tager dog afstand fra, at den naturlige religions fornuft kan forklare tilværelsen, og at man derfra kan slutte sig til Guds eksistens. Tværtimod mener 'vi'-fortælleren, at ordet hos mennesket, dvs. sproget og derigennem den menneskelige fornuft, ikke kan forklare sig selv og forstå mennesket, men ser sig selv som "Gaader" (str. 23,1-2) med en allusion til 1 Kor $13,12 .^{92}$ Kun Gud sidder inde med tilværelsesforklaringen, og han styrer alt. Han skabte vores sanser, tanker og sprog: "Han lærde vor Tunge / At tale og sjunge, / Han skabde vort Ord!" (str. 24). Herefter følger så en levende gengivelse af 1 Mos 1 formidlet af 'vi'-fortælleren, hvor skaberordet fra Gud har magt til at skabe, hvad det nævner (str. 25-36).$^{93}$ Den naturlige religion slutter fra skaberværket og dermed mennesket til Gud, mens Åbenbaringen

For den ældre oplysningsteologi kaldet supranaturalisme var der en nøje overensstemmelse mellem den religiøse erkendelses to kilder, fornuft og åbenbaring, men således at åbenbaringens sandhed ubetinget havde forrang for fornuftens. Den nye naturvidenskab øgede kendskabet til Guds underfulde skaberværk, og historien blev en eksempelsamling af vidnesbyrd om forsynets førelse. N. E. Balle (1744-1816), som Grundtvig ikke ukritisk livet igennem havde stor veneration for (jf. bl.a. GSV II, nr. 124), tilhørte denne retning. Hvor stærk indflydelse den naturlige religions forestillinger havde $\mathrm{i}$ datiden, kan blandt andet ses af lærebøgerne i kristendomsundervisningen for børn og unge, heriblandt Balles meget benyttede Larebog $i$ den evangeliskchristelige Religion fra 1791 og Matthias Galtens Catechetisk Udtog af S.T.Hr. Geheimeraad Ove Høegh Guldbergs aabenbarede Theologie fra 1784 (jf. Bugge 2006).

91 Jf. citatet fra strofe 9. Ifølge Herbert of Cherburys traktat De veritate, 1624; de øvrige hovedpunkter er: denne guddom skal æres, dyd og fromhed er det vigtigste i gudsdyrkelsen, last og forbrydelse må sones gennem anger, samt at der gives løn og straf efter dette liv (jf. Arendt, 1967, 24 f.). En anden berømt sammenfatning, Gud, dyd og udødelighed, bekendte blandt andet Jean-Jacques Rousseau (1712-78) sig til, men ligesom de senere romantikere kom han snarere frem til religionens sandheder gennem følelsen end fornuften.

92 "Thi vi se nu ved et speil i en mørk tale; men da [skal vi se] ansigt til ansigt" $(1$ Kor 13,12). Grundtvig, der tog udgangspunkt i den græske tekst,

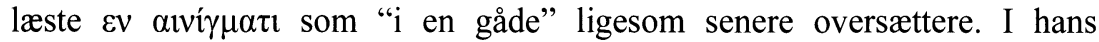
universalhistoriske forståelse vil gåden løses ved tidens ende.

93 Holdningen, der er udtrykt i digtet, minder om gudsbeviserne hos Thomas Aquinas (1225-75). Ved at bearbejde det sansede med vores fornuft føres vi til den erkendelse, at de sansede fænomener ikke kan forstås ud fra sig selv, men at de peger ud over sig selv til noget sidste og grundlæggende. Troen skal til for at identificere dette grundlæggende med Gud. Beviset er altså ikke et bevis i streng forstand. (se fx Bjelke 1970, 33 f.). 
kommer fra Gud til mennesket. Digtet har hentet inspiration fra den naturlige religions tilværelsestolkning, men tager afstand fra den. ${ }^{94}$

Ordet, forstået som skaberordet og det menneskelige ord, er digtets tema. På skabelsens sjette dag vil Gud lave og velsigne sin skabning "Til Ordet at ligne, / Saameget den vil!" (str. 33). Versene alluderer til 1 Johs. 1, hvor skabningen blev til ved ordet, der var Gud, og hvor ordet blev inkarneret i Jesus Kristus. I digtet er det op til mennesket selv, hvor meget det vil ligne Jesus og Gud. Ordet bliver igennem hele digtet draget frem som bindeleddet mellem Gud og mennesker. ${ }^{95}$ Ligesom Jesus selv er ordet ${ }^{96}$ og er søn af ordet, er det menneskelige ord i digtet som en søn af skaberordet: "Saa Ordet, I Unge, / Paa Menneske-Tunge / Har avlet en Søn!” (SBRK 1828, 153, GSV VI, 127, sp. 2). Derfor, opfordrer fortælleren, skal mennesket bruge sine ord til at lovprise skaberen.

På samme måde som der i $G S V$ II, nr. 1 bliver spillet på to forskellige teologiske tolkninger, der er aktuelle i samtiden, viser GSV II, nr. 2 to forskellige livssyn. Digtet handler om skabelsen af Eva (str. 1-6) og syndefaldet (str. 7-31) ${ }^{97}$ med forlæg i 1 Mos 2-3. I digtet udspiller der sig en dramatisk strid mellem forfatterpersonen, Gud og 'vi'-fortælleren på den ene side og slangen på den anden om Eva og Adams handlinger og den deraf udsprungne livserfaring og livsindstilling. Ligesom Adam og Eva er unge, er læserpersonen ung. Fristelsen foregår både "her" i Vesten, dvs. i Danmark, "som i Østen" (str. 15), hvor Edens have lå og "endnu" (str. 16) ligger, dvs. altid. Ungdom over hele jorden og til alle tider er særligt udsat og giver lettere efter for fristelser (str. 13).

Gud har indrettet verden til gunst for mennesket, der tror på ham og lyder hans bud: "Her voxer Livet, / Skiænket og givet / Troende Sind" (str. 12). Præmissen er, at verden tilhører Gud, "Riget er mit!" (str. 10), som der står med en allusion til Fadervor. Men ved blindt at rette sig efter Guds bud forbliver Adam og Eva i en barnlig og uskyldig lykketilstand. Som slangen udtrykker det: "Bange for Skarnet, / Mødes i Barnet / Engel og Fæ, / Daaren usyndig / Skyer ukyndig / Kundskabens Træ" (str. 20).

Slangen udnytter, at de unge er sårbare. Med stor indlevelse i modtagerens situation appellerer slangen til følelser og forstand (str.

94 Diskussionen om holdninger fra den naturlige religion videreføres $\mathrm{i}$ Grundtvigs store opgør med naturalisterne i indledningen til Nordens Mythologi, 1832.

95 Se fx str. $19-20$ og 24.

96 Jf. også allusionen til Jesu død og opstandelse i de i senere udgaver udeladte vers efter str. 22, hvor Ordet "kan døe, og opstaae".

97 Str. 32 er tildigtet til GSV II ${ }^{1}$. 
16-21 og 23-25), dels ved at friste modtageren til at vise positive egenskaber, der specielt hører ungdommen til som vovemod, nysgerrighed, videbegærlighed og viljestyrke, og dels ved at overbevise modtageren gennem argumentation ud fra sund fornuft og almene vurderinger eller ved at bruge ironi. Frem for alt appellerer slangen til Eva om at tage ansvar for sit eget liv: "Selv maa du raade, / Liv er en Gaade, / Lykken et Spil" (str. 23). At tage ansvar for sit eget liv er en naturlig del af den proces, det er at blive voksen, ligesom det er at kende forskel på godt og ondt og at blive opmærksom på sin seksualitet.

Slangens påstand om, at "Lykken" er et "Spil", det vil sige at tilfældighederne råder, står i modsætning til tro på Guds plan og styrelse. Når slangen siger, at "Liv er en Gaade", betyder det, at livet er uigennemskueligt som et spil. Med udsagnet "Selv maa du raade" giver slangen udtryk for en livsholdning, der indebærer, at mennesket må styre sit liv efter egne præmisser i modsætning til Guds forventning om, at det lyder hans bud. I 'vi'-fortællerens livsholdning i GSV II, nr. 1, str. 23 ses livet som nævnt også som en gåde. Her står udsagnet i sammenhæng med, at menneskets tale, dvs. forstand og dermed mennesket selv, ikke kan forstå sit eget liv, men er afhængig af Gud, som skabte det. I kraft af skabelsen, jf. GSV II, nr. 1, str. 33, står mennesket $i$ et valg og har råderet til at vælge det gode og adlyde Guds bud.

Eva og Adam kan vælge frit, men efter at deres valg er truffet, er kundskaben om godt og ondt og skismaet mellem hoved og hjerte (str. 27), dvs. mellem forstand og følelse eller viden og tro et grundvilkår for 'vi'-fortælleren og læserpersonen. ${ }^{98}$ Slangens overtalelsesforsøg i replikkerne til Eva er da også nok så meget henvendt til en ung, samtidig læserperson som til Eva. ${ }^{99}$ For en real modtager bliver Eva og med hende Adam et negativt forbillede, men af en mildere art end

98 "Vist gav om Ondskab / Synden ham Kundskab, / Men den var dyr!" (SBRK 1828, 161; GSV VI, 130, sp. 1), dvs. at Adam lærer at kende godt og ondt, får viden. Gud spørger Adam: "Smagte du Kvide, / Fik du at vide, / Ondt er ei Godt!" (Ibid.). "Født er nu Smerte, / Hoved og Hjerte / Stemme ei mer" (str. 27). Når Adam giver efter for det forbudte, får han kendskab til ondskab, og også smerten kommer ind i hans liv. Formuleringerne, specielt "Ondt er ei Godt!", ligger i tråd med Grundtvigs centrale begreb, modsigelsens grundsætning. Citatet str. 27 associerer også til det kristne grundvilkår, formuleret i Rom 7,15.

99 Jf. for eksempel at tilstanden efter syndefaldet og døden er forudsat $i$ argumentationen med den alment fornuftige påstand, at man må kende en sag fra begge sider for at kunne vurdere, hvad der er godt og ondt (str. 19), og ved appellen $i$ at friste med morskab og at leve livet, inden det er for sent (str. 24$25)$. 
Kain, da hun i modsætning til Kain angrer sin synd (SBRK 1828, 162; $G S V$ VI, 130, sp 1-2). Som i GSV II, nr. 1 er 'vi'-fortælleren meget fremtrædende, og hans holdninger er i begge digte sammenfaldende med forfatterpersonens og Guds ligesom i GSV II, nr. 6.

Det lange digt GSV II, nr. 8 "Syndfloden" med forlæg i 1 Mos 6-9 tilfører ikke noget væsentligt nyt, hvad angår de forkyndende elementer. Stilmæssigt ligger det tættest på GSV II, nr. 1 og 2 med sin længde, ${ }^{100}$ svært forståelige allegori, ${ }^{101}$ læserhenvendelser ${ }^{102}$ og omfattende udvidelser fra fortællerens side. Hentydningerne til samtidens teologiske debat og diskussion af livssyn svarer indholdsmæssigt til den sværere tilgængelige digteriske iklædning af digtene GSV II, nr. 1, 2 og 8 . I disse rim dominerer det 3 . moralske niveau over det historiske, hvad der ikke var tilfældet i $G S V$ II, nr. 6+7. Den eksplicitte læserperson i GSV II, nr. 1 og 2 er den "Unge", og den implicitte i $G S V$ II, nr. 8 er i hvert fald ikke noget mindreårigt barn, mens læserpersonen som nævnt var børn og lægmænd i GSV II, nr. 6+7. Også i versemålene adskiller de to grupper sig. ${ }^{103}$ Ligesom med den samtidige bibelhistorie kunne man forestille sig, at Grundtvig som reelle modtagere både har haft elever i børneskolen og unge i konfirmandforberedelsen i tankerne. $G S V$ II, nr. 6+7 er så primært skrevet med henblik på de yngre børn, mens $G S V$ II, nr. 1, 2 og 8 er blevet til med de unge konfirmander som målgruppe.

Et stiltræk er stærkere i GSV II, nr. 8 end i de øvrige digte i udgivelsen, nemlig inspirationen fra den norrøne heltedigtning. Det var naturligt for Grundtvig at gøre den bibelske urhistorie mere tilgængelig for et dansk publikum ved også at brnge stiltræk fra tilsvarende stof hentet fra den nordiske mytologi. Indholdsmæssigt svarer den nordiske mytologis oprindelses- og undergangsmyter til den bibelske urhistorie med skabelse, nedbrydelse af kosmos med blandt andet brodermord ${ }^{104}$ og verdens undergang og genskabelse, hvor syndfloden må forstås som en præfiguration af den endelige dom.

Den celdre Eddas traditionelle opdeling i gude- og heltedigtning bliver hos Grundtvig til en bibelsk heltedigtning, hvor det om Noah hedder "Heltens Iil" ( $G S V$ II, nr. 8,23), og hvor han bliver betegnet

100 GSV II, nr. 1 har verslinjer, der svarer til ca. 43 strofer; GSV II, nr. 2 har 41 strofer; GSV II, nr. 8 har 54 strofer.

101 GSV II, nr. 1, str. 15-19; II, nr. 8, str. 34-41.

102 GSV II, nr. 1, str 1, 6, 11 og 14 etc.; II, nr. 2, str. 14; II, nr. 8, str. 42 og 54.

103 Versemålet i GSV II, nr. 6+7 ligner som nævnt den 4-linjede ballade uden omkvæld, mens versemålene i GSV II, nr. 1, 2 og 8 er inspirerede af eddaversemålet ljóðaháttr. Se nedenfor.

104 Kains drab af Abel svarer til Høders drab af Balder. 
som "Drot" (GSV II, nr. 8,47). Påvirkningen viser sig i billedbrugen, som når Gud spiller med guldterninger ( $G S V$ II, nr. 2,2) ligesom aserne i "Vølvens Spådom", ${ }^{105}$ og når kvinder bliver omtalt som diser, dvs. gudinder (GSV II, nr. 8,5). ${ }^{106}$ Især i GSV II, nr. 8 er adskillige billeder dannet på samme måde som kenninger, for eksempel "Lynilds Blik" for vrede (GSV II, nr. 8, str. 4) og "Storvragets Master" for jordens bjergtinder (GSV II, nr. 8, str. 43). ${ }^{107}$ Endvidere er strofeformerne i GSV II, nr. 1, 2 og 8 på hver deres måde inspirerede af det 6-linjede eddaversemål ljóðaháttr, og digtene indeholder mange eksempler på allitterationer. ${ }^{108}$ Forekomst af enkelte stiltræk fra den norrøne digtning bliver et karakteristisk særpræg for Grundtvigs bibel- og kirkehistoriske salmer og sange.

Som på så mange andre punkter adskiller Grundtvig sig også her fra samtidens litterære hovedstrømninger. Brug af norrøne motiver og stiltræk var karakteristisk for dansk førromantik og den følgende universalromantik. Et af den poetiske realismes kendetegn var at lægge vægt på lokal- og tidskolorit, således at man med karakteristiske detaljer forankrede digtningen til virkeligheden. ${ }^{109}$ Grundtvig går den modsatte vej og gør det historiske eviggyldigt og nutidigt og det eksotiske allestedsnærværende og hjemligt. Han vil ikke bare underholde eller belære, men han bruger de redskaber, han har til rådighed, for at budskabet kan blive personligt og appellere til en samtidig, hjemlig modtager.

Hvis man sammenholder Grundtvigs teoretiske udtalelser omkring udgivelsestidspunktet for "Studier til en bibelsk Rimkrønike" med hans praksis, slår som forventet den genremæssige inspiration fra rimkrøniken tydeligt igennem i digtene. I et første manuskript til GSV

105 Se Larsen 1943, 8 og 61

106 Se også “De Kuld uægte / Af Asa-Æt!"” om gudesønnerne (GSV II, nr. 8, str. 9); jætter og trolde (II, nr. 8, str.7); "Valravn” (II, nr. 8, str. 45).

107 Se også "Kains Skik" for onde gerninger (GSV II, nr. 8, str. 4), "Vintermark" for havet (II, nr. 8, str. 15), "Himmel-Guldet" for Gudsbilledet (II, nr. 8, str. 40), "Bølge-Salen" for rum i arken (II, nr. 8, str. 17 og 51), "Noahs By" for arken (II, nr. 8, str. 26) og den ægte kenning "Havets Hest" for skib (II, nr. 8, str. 17).

108 Eks.: GSV II, nr. 2, str. 9 og 15; GSV II, nr. 8, str. 2-4, 13 og 20.

109 Jf. bl.a. Dansk Litteraturhistorie, b. II (1965) 250, hvor Oluf Friis anfører om poetisk realisme: "Et af tidens æstetiske programpunkter blev kravet om lokalkolorit. Ideen er overtaget fra den ældre romantik. Oehlenschläger havde stræbt at give sin Vaulundur og sin Aladdin en "ganske forskiellig Colorit". Men kravet fremsættes nu mere bevidst, ikke blot rettet mod det eksotiske og fremmedartede, men netop som opmærksomhed for det fortroligt hjemlige, den konkrete detalje, der fortæller om inderliggjort virkelighedsstudium." 
II, nr. 6 begynder digtet ligefrem med et citat fra et af rimene i rimkrøniken. Begge steder tematiserer den middelalderlige dødssynd "Avind" en konflikt. ${ }^{110}$ Stroferne kom ikke med i udgivelsen, men anes i str. 6 om "Avind" i Guds tale, der som et eksempel på synd (str. 5) nu kaldes en herskende dronning (personifikation). Nok så vigtigt er det, at både rimkrøniken og de bibelske krønikerim bruger forbilleder og negative forbilleder som middel til at påvirke modtagerne, ligesom begge værker har til hensigt at være kundskabsmeddelende, moraliserende og underholdende. Værkerne er enkeltfortællinger om mænd og tildragelser og kan karakteriseres som episk-dramatisk gengivelse af historisk stof på vers. ${ }^{111}$ Grundtvigs digte er således stilmæssigt påvirkede både af den norrøne og den middelalderlige danske heltedigtning.

Når Grundtvig ikke er tilfreds med digtene i studierne, skyldes det næppe disse afvigelser fra hensigterne, men at de pædagogiske intentioner ikke er opfyldt. Digtene er sandsynligvis ikke livlige nok til, at børnene gider høre dem, og til at han selv synes, de er værd at huske. GSV II, nr. 1, 2 og 8 er formentlig skrevet med henblik på at blive brugt i konfirmationsforberedelsen, hvor de store børn står på grænsen til at blive unge. Selv om Grundtvig er opmærksom på, at konfirmandundervisningen i højere grad skal indrettes efter elevernes faglige, personlige og religiøse udvikling, vil de færreste i denne målgruppe dog kunne værdsætte digtenes komplicerede billedsprog.

Det er desuden vigtigt at notere sig, at digtene i studierne er rim og ikke sange. ${ }^{112}$ Som digtene fremtræder, er ingen af dem sangbare på grund af længden, og gruppen $G S V$ II, nr. 1, 2 og 8 er desuden uegnede til fællessang ved at indeholde lange, svært forståelige allegorier og kommentarer og ved, at GSV II, nr. 1 ikke er strofeinddelt.

"Studier til en bibelsk Rimkrønike" er et første forsøg på begyndelsen til en lærebog på vers i bibelhistorie for kristne børn, unge og forældre.

\section{Forkortelser}

Fasc.: Fascikel, dvs. håndskriftskapsel i N. F. S. Grundtvigs Arkiv på Det Kongelige Bibliotek.

110 Se håndskrift fra 1828 i fasc. 381; jf. Toldberg 1961, 42.

111 Stilmæssigt kan der findes endnu flere ligheder m.h.t. sprog og brug af citater fra Bibelen, folkeviser, ordsprog og folkelige talemåder. Monologformen fra rimkrøniken benytter Grundtvig i $K R \quad 1829$, og et af digtene herfra er optaget i GSV II 1870 som nr. 105.

112 Jf. Bugge 1978, 50. 
GSV I-VI: Balslev, Th., Borup, Ernst, Hansen, Uffe, Skovrup, Ejnar og Stevns, Magnus (udg.) (1944-64) (fotografisk optr. 1982-84), Grundtvigs Sang-Verk. Samlet Udgave, bind 1-6, København.

KR 1829: Grundtvig, N. F. S. (1829), Krønike-Riim til Børne-Lardom med Indledning og Anmoerkninger, København.

LBK 1828: Grundtvig, N. F. S. (1828), En liden Bibel-Krønike for Børn og Menig-Mand, 2. omarb. udg., København.

PS I-IX: Svend Grundtvig et al. (udg.) (1880-1930), N. F. S. Grundtvigs Poetiske Skrifter, bind 1-9, København.

SBRK 1828: Grundtvig, N. F. S. (1828), "Studier til en bibelsk Rimkrønike" i Theologisk Maanedsskrift, bind 13, 145-181, imprimatur 14. juli 1828.

US I-X: Holger Begtrup (udg.) (1904-09), Nik. Fred. Sev. Grundtvigs Udvalgte Skrifter, bind 1-10, København.

VK 1812: Grundtvig, N. F. S. (1812), Kort Begreb af Verdens Krønike $i$ Sammenhoeng i US II, 165-422.

VU I-X: Christensen, Georg og Koch, Hal (udg.) (1940-49), N. F. S. Grundtvigs Varker i Udvalg, bind 1-10, København.

\section{Litteraturliste}

\section{Voerker af Grundtvig}

Balslev, Th. et al. (1944-64) (fotografisk optr. 1982-84), Grundtvigs SangVark. Samlet Udgave, bind 1-6, København.

Begtrup, Holger (udg.) (1904-09), Nik. Fred. Sev. Grundtvigs Udvalgte Skrifter, bind 1-10, København.

Borup, Ernst J. og Schrøder, Fredrik (udg.) (1929-31), Haandbog i N. F. S. Grundtvigs Skrifter, bind 1-3, København.

Brandt, C. J. (udg.) (1877), Kirkelige Leilighedstaler af N. F. S. Grundtvig, København.

Christensen, Georg og Koch, Hal (udg.) (1940-49), N. F. S. Grundtvigs Vorker i Udvalg 1-10, København

Grundtvig, N. F. S. (10. april 1811), "Hr. Sandsiger!” i K. L. Rahbeks ugeskrift Sandsigeren; her efter US II, 77-82.

- (1812), Kort Begreb af Verdens Krønike i Sammenhweng i US II, 165-422.

- (1825), Kirkens Gienmale i VU II, 317-349.

- (1826-27), "Om den sande Christendom" og "Om Christendommens Sandhed", 12 afhandlinger i Theologisk Maanedsskrift, København.

- (1828), En liden Bibel-Krønike for Børn og Menig-Mand, omarb. udg., København.

- Fasc. 146.8.b.; her citeret efter Bugge 1978.

- (1828), "Studier til en bibelsk Rimkrønike" i Theologisk Maanedsskrift bind 13, 145-181, imprimatur 14. juli 1828, København.

- (1828), "Kingos Psalmer udgivne af Fenger. Af N. F. S. Grundtvig, præst", anmeldelse i Theologisk Maanedsskrift, København, bind 13, 136.

- (1829), Krønike-Riim til Børne-Lardom med Indledning og Anmorkninger, København. 
- (1870), Melodier til N. F. S. Grundtvigs Sang-Vark til den danske KirkeSkole, København.

Grundtvig, Svend (udg.) (1875), Grundtvig, N. F. S., Krønike-Rim til levende Skolebrug, med Indledninger og Oplysninger, København.

— et al. (udg.) (1880-1930), bind 5 og 6 i N. F. S. Grundtvigs Poetiske Skrifter, bind 1-9, København.

\section{Vaerker af andre forfattere}

Albeck, Gustav, Friis, Oluf, og Rohde, Peter P. (1965), Dansk Litteraturhistorie, bind 2, København.

Allchin, A. M. (2002), Grundtvigs kristendom. Menneskeliv og Gudstjeneste, Århus.

Andersen, Vilhelm (1924), Illustreret dansk Litteraturhistorie, bind 3, København.

Arendt, Rudolf (1967), Toenkning og Tro, København.

Auerbach, Erich, "Figura (oversat af Anton Jørgensen)" i Transfiguration Nordisk tidsskrift for kunst og kristendom, 1. årg., dec. 1999, nr. 2., København, 95-148.

Auken, Sune (2005), Sagas spejl. Mytologi, historie og kristendom hos N. F. S. Grundtvig, København.

Balling, J. L. og Lindhardt, P. G. (1979), Den nordiske kirkes historie, 4. udg., København.

Biblia (1787), reviderede 13. oplag, København.

Bjelke, J. F. (1970), Den europæeiske filosofi, Oslo.

Bugge, K. E. (1965), Skolen for livet. Studier over N. F. S. Grundtvigs poedagogiske tanker, København.

— (1978), "Grundtvigs bibelhistoriske sange" i Ingrid Markussen og Vagn Skovgaard-Petersen (red.), Festskrift til Roar Skovmand, Årbog for dansk Skolehistorie, 12, København, 36-53.

- (1983), "Grundtvigs pædagogiske tanker" i Thodberg 1983, 210-224.

- (2006), "En upåagtet dimension i Grundtvigs tanker om 'Anskuelsen"” i Grundtvig-Studier 2006, København, 53-66.

Holmgaard, Otto (1951), Kirkeskolen, København.

Høirup, Henning (1962), “Grundtvigs syn på dåbspagtens bekræftelse og på konfirmandundervisningen" i L. Brøndum (red.), Konfirmandundervisning og konfirmation, København.

Larsen, Martin (1943), Den celdre Edda og Eddica Minora. Oversatte og forsynede med Indledning og Kommentar, bind 1, København.

Ludwigs, Chr. (1919), "Grundtvigs Bibel" i Højskolebladet, København, sp. 501-508.

Luther, Martin (1962), "Om et kristenmenneskes frihed" i Nøjgaard, Niels (red.), Luthers Skrifter i Udvalg, bind 1, København, $282 \mathrm{ff}$.

Mogensen, Bent (1972), Kommentarhoifte til den bibelske Urhistorie. Genesis $1-11$, København.

Nøjgaard, Niels (red.) (1962), Luthers Skrifter i Udvalg, bind 1, København. 
Riisager, Else (2009), Grundtvigs kristelige paedagogik. N. F. S. Grundtvigs kristeligt paedagogiske tanker og digte til "Sang-Vark til Den Danske Kirke-Skole" i perioden 1810-41 (utrykt speciale).

Thyssen, Anders Pontoppidan (1983), "Grundtvigs tanker om kirke og folk 1825-47" i Thodberg 1983, 225-286.

Thodberg, Christian og Thyssen, Anders Pontoppidan (red.) (1983), Grundtvig og grundtvigianismen i nyt lys, Århus.

Thodberg, Christian (1998), "Grundtvig og Gammel Testamente - den danske Bibel eller Septuaginta?”, Grundtvig-Studier 1998, København, 61-80.

Toldberg, Helge (1950), Grundtvigs Symbolverden, København.

- (1954), "Grundtvig og Den danske Rimkrønike" i Grundtvig-Studier 1954, København, 40-95.

— (udg.) (1961), Den danske Rimkrønike, bind 1, København. 